\title{
The University of Alicante Library copy of Palmerin d'Oliva (London, 1637): A Bibliographical Description
}

\author{
Jordi Sánchez-Martí \\ University of Alicante
}

\begin{abstract}
The purpose of this article is to provide bibliographical information about a copy of the fourth edition of the two parts of Anthony Munday's translation of Palmerin d'Oliva (London, 1637; STC 19160) recently purchased by the University of Alicante Library and not mentioned in the standard bibliographies. The article contains a detailed bibliographical description based on Bowers's principles (1949) and is designed to be useful to scholars by making direct consultation of the copy in most cases unnecessary. The description is preceded by a short introduction to the literary text and its publication in England."

KEYWORDS: Renaissance chivalric literature, Hispanic romances of chivalry, Anthony Munday, Palmerin d'Oliva, Thomas Creed, Bernard Alsop, Thomas Ottley.
\end{abstract}

\section{o. Introduction}

In 1511 Juan de Porras printed the first edition of the anonymous Spanish romance of chivalry Palmerín de Olivia (Salamanca; IB 16737) in the hope of replicating the commercial success achieved by Amadis de Gaula three years earlier (Saragossa, 1508; IB 16414). This publishing decision proved profitable in view of the number of

\footnotetext{
* Research for this article was funded by the Spanish Ministry of Science and Innovation (ref. FFI2011-22811), whose support is herewith gratefully acknowledged. I would also like to thank the staff at the University of Alicante Library, especially Berenice Santonja and María Játiva Victoria, for their diligence and assistance. All images are reproduced by permission of the University of Alicante Library.
}

$$
\text { (C) ederi 23 (2013: 123-137) }
$$

https://doi.org/10.34136/sederi.2013.6 
editions of Palmerin de Olivia printed throughout the sixteenth century (fifteen in total; IB 16737-16751). Soon the literary fame of Palmerín prompted the composition and publication of new adventures involving the hero and his progeny, including such texts as Primaleón (Saragossa, 1512; not in IB), Platir (Valladolid, 1533; IB 16777), and the Portuguese Palmeirim de Inglaterra by Francisco de Moraes (1543-1544; a Spanish translation appeared in Toledo in 15471548; IB 16732-16733). ${ }^{1}$ This literary phenomenon crossed over the Pyrenees and extended across the Continent. Palmerin de Olivia was first translated into Italian by Michele Tramezino in 1544 and into French by Jean Maugin in 1546 (FB 40395), on whose version the English translation is based. ${ }^{2}$

Anthony Munday (bap. 1560-d. 1633), the English translator, began translating Iberian chivalric romances around 1580 , as can be gathered from the prefatory epistle to his Zelauto (1580), where Munday informs his patron Edward de Vere, 17th Earl of Oxford, that "Not long it will be before [...] the renowned Palmerin of England with all speede shall be sent you" (1963:6). ${ }^{3}$ After translating Palmerin of England, Munday started work on his translation of Palmerin d'Oliva,

\footnotetext{
${ }^{1}$ For a discussion of the Spanish cycle of Palmerín and its authorship, see Marín Pina (1996); for the cycle's English dissemination, see Patchell (1947). For an edition of the Spanish text, see Palmerin de Olivia (2004). Thomas's discussion (1920) of the genre of Iberian chivalric romance is still useful; for a more up-to-date bibliography, however, see Eisenberg and Pina (2000) and the on-line database prepared by Cacho Blecua and Lacarra. For bibliographical descriptions of the Spanish editions of the Palmerín cycle, see García Dini (1966). For Palmeirim de Inglaterra, see Purser (1904).

2 As Galigani (1966:253-254,281-282) has argued, the English translator must have consulted an Italian version of the text. For an analysis of the French translation, see Bettoni (1995:173-201).

${ }^{3}$ For a bibliographical discussion of the chivalric texts translated by Munday, see Hayes (1925, 1926). See also Hamilton (2005:73-112), Phillips (2010:121-151) and Turner (1928:180-183). Since the earliest surviving copy of Palmerin of England is from the 1596 edition, Hamilton contends that this romance might not have been printed until then. This view has not gained scholarly support and more recently Moore has maintained that "Munday probably began his enterprise with the two parts of Palmerin of England" (2010:338). Whether Palmerin of England was printed first in 1581 or 1596, there is no denying that this is the first chivalric romance Munday translated into English. For biographical information on Munday, see also Bergeron (2004) and Hill (2004). On Edward de Vere, see Nelson (2004). Munday's translation of Amadís de Gaula is available in a scholarly edition (Moore:2004). I am currently preparing a critical edition of his Palmerin d'Oliva to appear in the series Medieval and Renaissance Texts and Studies of the Arizona Center for Medieval and Renaissance Studies.
} 
which was published for the first time in 1588 (STC 19157) with a dedication to the same patron as his Zelauto. That translation was reprinted in 1597 (STC 19158) with a change in the dedicatee: instead of the Earl of Oxford, the second edition is dedicated to Francis and Susan Young. ${ }^{4}$ The third edition of Palmerin d'Oliva was published in 1615-1616 (STC 19159, 19159a) by Thomas Creede in collaboration with Bernard Alsop. ${ }^{5}$ The latter was also involved in the fourth edition of 1637 (STC 19160), a copy of which has been newly acquired by the University of Alicante Library. Alsop also worked with an associate, as the title-page indicates: "for B. ALSOP and T. FAWCET, dwelling in Grub-street neere the lower Pumpe."6 When Thomas Creede died in 1616 Alsop inherited his printing equipment (Yamada 1994:11) and later formed a partnership with Thomas Fawcet, who became free of the Company of Stationers on 7 May 1621. ${ }^{7}$ It should therefore come as no surprise that some of Creede's ornaments and ornamental capitals reappear in the 1637 edition of Palmerin d'Oliva, as the bibliographical description below reveals.

As in the case of the third edition, the first part (henceforth Palmerin d'Oliva I) of the 1637 edition is dedicated to the Youngs and the second part (henceforth Palmerin d'Oliva II) to Edward de Vere. Such a correlation suggests that the fourth edition is descended from the third, a logical possibility considering both Alsop's participation in the printing of the latter and the chronological sequence of the editions. In the only article to date discussing the genetic relation of the four editions, Hayes initially states that the 1637 edition was "identical with that of 1616" (1925:70). Confusingly, later in the article Hayes (1925:75-76) seems to suggest that Palmerin d'Oliva I is based not on the third but on the second edition and that the 1637 Palmerin d'Oliva II is a reprint of the first edition. Hayes provides no textual evidence to support either of these claims, which seem to be based on the identity of the dedicatees of both parts of the romance:

\footnotetext{
${ }^{4}$ Wilson (2011:126) states that Young was a merchant.

${ }^{5}$ For biographical information on Creede, see Gants (2004) and Yamada (1994:3-11). For information on Alsop, see Plomer (1907:3-4).

${ }^{6}$ Note that the STC mentions a variant imprint replacing for with by. This variant occurs in the copy at the John Rylands University Library of Manchester. For locating the whereabouts of Alsop's printshop, see STC, 3:251 (I.6).

${ }^{7}$ Cf. Arber 3: 685, 700, 701. For more biographical information on Fawcet, see Plomer (1907:72).
} 
the second edition (like the third and fourth edition of Palmerin $d^{\prime}$ Oliva $I$ ) is dedicated to the Youngs and the first edition (like the third and fourth edition of Palmerin d'Oliva II) to Edward de Vere. An example will suffice to disambiguate Hayes's position. On the final page of chapter 1 of Palmerin d'Oliva I, the 1637 edition, in agreement with the third edition, reads, "but by consent of the Emperour and I" (sig. $7^{\mathrm{v}}$; my italics). By contrast, the first and second editions depart from the other two in reading, "but the Emperour and I." As to Palmerin d'Oliva II, the fourth edition on the last page of chapter 1 reads, "conducted her into a most Princely Chamber" (sig. $\mathrm{A} 6^{\mathrm{v}}$; my italics), again agreeing with the third, whereas the second edition reads "conducted her into a marvailous princely Chamber" (my italics; no copy of the first edition of Palmerin d'Oliva II survives). These two examples show a correspondence between the third and the fourth editions and a departure of these two editions from the second, thus confirming that the 1637 edition is textually derived from the third edition of 1615-1616.

\section{Bibliographical Description}

\section{Volume 1}

Title-page: Palmerin D'Oliva. | THE FIRST PART: | [rule] SHEWING | THE MIRROVR OF NOBI- | litie, the Map of Honour, Anatomie of rare | Fortunes, Heroicall prefidents of Love, won- $\mid$ der of Chivalrie, and the moft accomplifhed | Knight in all perfection. | [rule] Prefenting to Noble minds, their Courtly defire, | to Gentiles their expectations, and to the inferiour | fort, how to imitate their Vertues: Handled with | modeftie to hun offence, yet delightfull | for Recreation. | [rule] Written in Spanilh, Italian, and French: and from | them turned into Englifh, by A. M. one of the | Meflengers of his Majefties | Chamber. | Patere \& A[swash itl.]bstine $>$. | [orn. Yamada 15] | LONDON, | Printed for B. ALSOP and T. FAVVCET, dwelling in | Grub-Jtreet neere the lower Pumpe. | 1637.

Head-title: [double rule] [orn.] THE FIRST PART | OF THE ANCIENT | and honourable Hiftorie of the | valiant Prince Palmerin D'Oliva, | Emperour of Conftantinople ; | Sonne to King FLORENDOS of Macedonia, | and the Faire GRIANA, Daughter to Re- | micius, 
Emperour of Conftantinople : | a Hiftory full of fingular and | Courtly recreation. [rule].

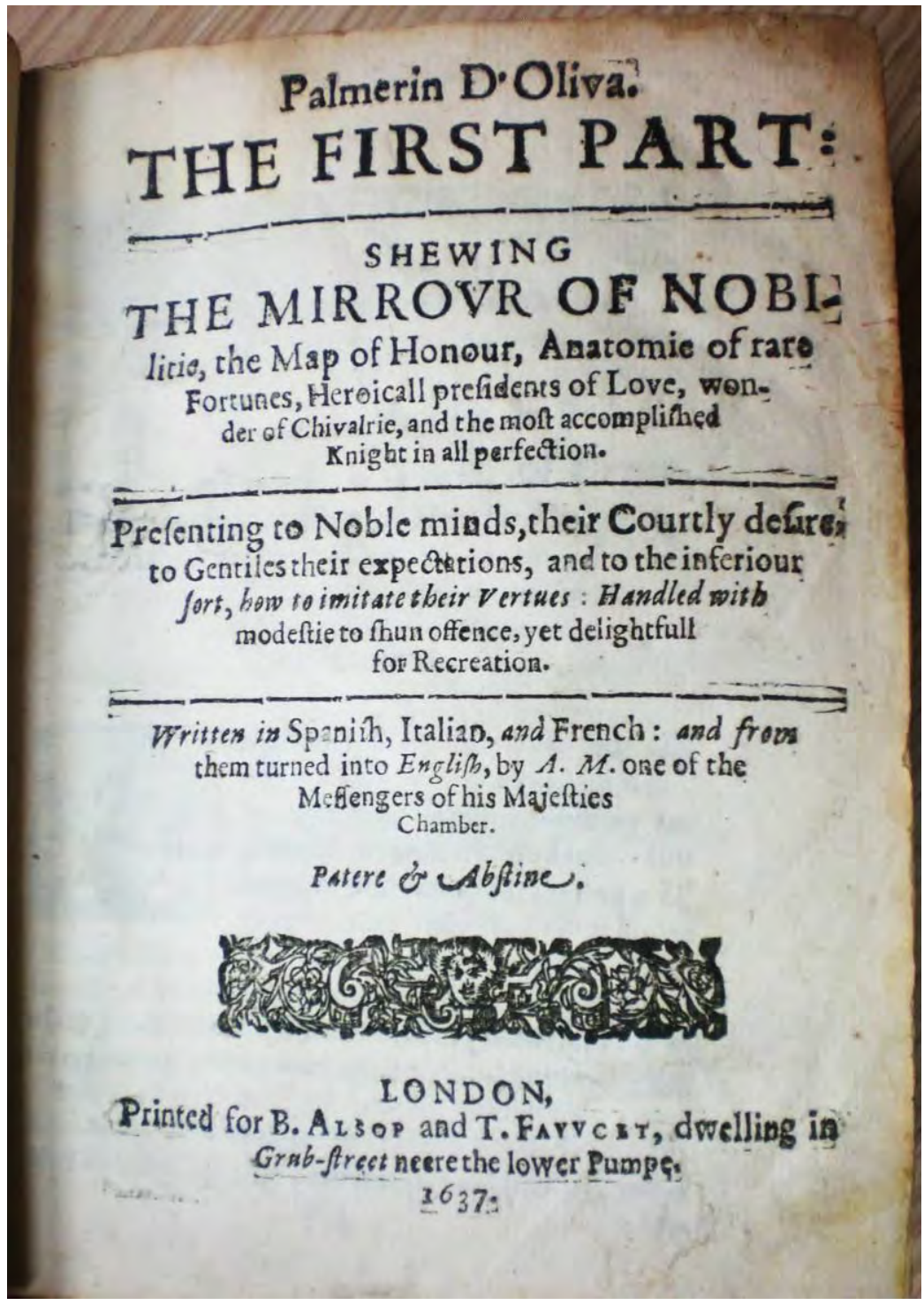

Figure 1. Palmerin d'Oliva, part I (London, 1637), title-page. 
Running-title: [rule] The Hiftorie of Palmerin D'Oliva, | Emperour of Conftantinople. PART. 1. [rule] [Hiftory $\mathrm{A}_{5}-8^{\mathrm{v}}, \mathrm{B}_{1}^{\mathrm{v}}, \mathrm{B}_{3}-4^{\mathrm{v}}, \mathrm{C}_{1}^{\mathrm{v}}, \mathrm{C}_{3}{ }^{\mathrm{v}}$, $\mathrm{D} 2-3^{\mathrm{v}}, \mathrm{E}_{1}{ }^{\mathrm{v}}, \mathrm{E} 3^{\mathrm{v}}, \mathrm{F} 2-3^{\mathrm{v}}, \mathrm{G} 2-3^{\mathrm{v}}, \mathrm{H}_{3} \mathrm{v}, \mathrm{H}_{7}-8^{\mathrm{v}}, \mathrm{I} 6-7^{\mathrm{v}}, \mathrm{K} 6-7^{\mathrm{v}}, \mathrm{L}_{5}{ }^{\mathrm{v}}, \mathrm{L}^{\mathrm{v}}, \mathrm{M}_{5}^{\mathrm{v}}$, $\mathrm{M}_{7}^{\mathrm{v}}, \mathrm{N}_{7}-8^{\mathrm{v}}, \mathrm{O} 6-7^{\mathrm{v}}, \mathrm{P}_{5}-6^{\mathrm{v}}, \mathrm{Q}_{7}-8^{\mathrm{v}}, \mathrm{S}_{5}^{\mathrm{v}}, \mathrm{S}^{\mathrm{v}}, \mathrm{T} 6^{\mathrm{v}}, \mathrm{T} 8^{\mathrm{v}}, \mathrm{V} 6-7^{\mathrm{v}}, \mathrm{X} 6^{\mathrm{v}}, \mathrm{X}^{\mathrm{v}}$, $\mathrm{Y} 7^{\mathrm{v}} ; \mathrm{Y}^{\mathrm{v}}-7^{\mathrm{r}}$ invert the two parts of the RT; $\mathrm{Y}^{\mathrm{v}}-\mathrm{Z}^{\mathrm{r}}{ }^{\mathrm{r}}$ print ${ }^{\mathrm{N}}$ Emperour of Conftantinople. PART. 1.' in both parts of RT].

Collation: $4^{\circ}: \mathrm{A}-\mathrm{Y}^{8}, \mathrm{Z}^{4}\left[\$_{4}\left(-\mathrm{A}_{2}, \mathrm{Z}_{4}\right)\right.$ signed; missigning $\mathrm{O}_{3}$ as $\mathrm{O}_{4}$, $\mathrm{S}_{2}$ as $\left.\mathrm{S}_{4}\right], 180$ leaves unnumbered.

Contents: $\mathrm{A} 1$ (blank apart from signature). $\mathrm{A} 2^{\mathrm{r}}$ : title-page (verso blank). $\mathrm{A}^{\mathrm{r}}$ : [double rule] [orn.] | TO | THE WORSHIPFVLL, $\mid \mathrm{M}^{\mathrm{r}}$. FRANCIS YONG, of B[swash ital.]rent- | Pellam [stet], in the County of Hertford Efquire, $\mid$ and to Miftrefle SVSAN YONG his wife, $\mid$ and my moft kind Miftreffe $>$, health, and | their hearts contentment, con- | nually [stet] wilhed.' ital. with 6-line init. $\left(26 \times 26 \mathrm{~mm}\right.$.). A3 ${ }^{\mathrm{v}}$ : dedication ending 'Your poore well-willer | till death, |A. M.' [rule] [orn. Yamada 14] A4: [double rule] [type orn.] 'To the Reader.' rom. with 10line init. $(38 \times 40 \mathrm{~mm}) . \mathrm{A}_{5}^{\mathrm{r}}-\mathrm{Z}_{4}$ : HT and text [b.l.], chap. $1-65$, chap. hd. in rom. except for proper names. $\mathrm{Z}_{4}{ }^{\mathrm{r}}$ : 'FINIS' followed by recapitulation and announcement by the translator, 'A. Mundy. Honos alit Artes.' (verso blank).

Catchwords: $\mathrm{B}_{2}{ }^{\mathrm{v}}$ day [day,] $\mathrm{B}_{4}^{\mathrm{v}}$ here, [heere,] $\mathrm{C}_{2}{ }^{\mathrm{r}}$ (se-)cretly [cretly,] C $8^{\mathrm{v}}$ she [shee] $\mathrm{Di}^{\mathrm{r}}$ yongest [youngest] $\mathrm{E}^{\mathrm{r}}$ faid [fayd] $\mathrm{F}^{\mathrm{v}}$ lone [love] $\mathrm{H}_{5} \mathrm{v}$ folemnized [folemnized,] $\mathrm{H}^{\mathrm{v}}$ (Ptolo-)mes [mies] $\mathrm{I}^{\mathrm{r}}$ (dif-)courle, [difcourfe,] (him-)felfe [felfe,] $\mathrm{M}_{5}^{\mathrm{r}}$ death [death,] $\mathrm{M}^{\mathrm{v}}$ Staves [Staues] $\mathrm{M} 8^{\mathrm{r}}$ accom- [acoompany] $\mathrm{M} 8^{\mathrm{v}}$ having [hauing] $\mathrm{Ni}^{\mathrm{r}}$ (of-)teu [ten] $\mathrm{O}_{3}{ }^{\mathrm{r}}$ world. [world,] $\mathrm{O}_{4}{ }^{\mathrm{v}}$ Country [Countrey] $\mathrm{O}_{5}{ }^{\mathrm{r}}$ (pro-)céeding [céeding,] O8 ${ }^{\mathrm{v}}$ CHAP. XLII. [CHAP. XLIII.] $\mathrm{P}_{1}{ }^{\mathrm{r}}$ happe [hap] $\mathrm{P}^{\mathrm{r}}$ Citty [City,] $\mathrm{P}_{7}^{\mathrm{r}}$ con- [Conquer] $\mathrm{Q}^{\mathrm{v}}$ (beau-)ty [tie] $\mathrm{Q}^{\mathrm{r}}{ }^{\mathrm{r}}$ loofe [lofe] Q8 ${ }^{\mathrm{v}}$ CHAP. XLVIII. [CHAP. L.] $\mathrm{R}_{3}{ }^{\mathrm{r}}$ refpect [refpect,] $\mathrm{R}_{5}{ }^{\mathrm{r}}$ (vnhappi-)ly [lie] $\mathrm{R}_{5}{ }^{\mathrm{v}}$ fighes [fighes,] $\mathrm{V}_{2}^{\mathrm{v}}$ Befides, [Befides] $\mathrm{V}^{\mathrm{r}}$ (afflicti-)ons [ons,] $\mathrm{X}_{1}{ }^{\mathrm{r}}$ neuer [never] $\mathrm{X}_{4}{ }^{\mathrm{v}}$ (Pal-)merin [merin,] $\mathrm{Y}_{5}{ }^{\mathrm{v}}$ finger [finger,] $\mathrm{Y}^{\mathrm{r}}$ Believe [Beléeue] $\mathrm{Z}_{1}{ }^{\mathrm{r}}$ (deter-)mined [determined] $\mathrm{Z}_{2}{ }^{\mathrm{v}}$ (afflicti-)ons? [afflictions?]; no $\mathrm{cw}$ on $\mathrm{Mr}^{\mathrm{r}}, \mathrm{M}_{4}{ }^{\mathrm{v}}$ [probably damaged].

Typography: 35 ll., 144 ( 160 to top rule of headline) x $90 \mathrm{~mm}$. $\left(\mathrm{H}_{1} \mathrm{v}\right)$; text, black letter (and some roman and italic) $82 \mathrm{~mm}$. for $20 \mathrm{ll}$;; dedication: italic $94 \mathrm{~mm}$. $\left(\mathrm{A}_{3}{ }^{\mathrm{r}}\right)$; 'To the Reader.': roman $82 \mathrm{~mm}$. $\left(\mathrm{A}_{4}{ }^{\mathrm{v}}\right)$; headline roman and italic. Capitals used from Thomas Creede's 
stock (following Yamada 1994: 84-86): B1 (ch. 21, 57), E1 (ch. 13, 28, 61), $F_{1}$ (ch. 7), Gi (ch. 26, 35), L1 (ch. 32), Mi (ch. 24), N1 (ch. 50), an altered form of Q1 used for ' $\mathrm{O}^{\prime}$ ( (ch. 22, 36, 44, 63), P1 (ch. 30, 38, 55), $\mathrm{S}_{1}(34,39,42,56), \mathrm{T}_{1}$ (ch. 27, 64), T2 (ch. 59; see fig. 2), ${ }^{8} \mathrm{~T}_{3}$ (ch. 15, 23, 40, 46, 51, 62), V1 (ch. 20, 43), W1 (ch. 9, 16, 17, 47, 49, 58), Y1 $(12,18)$.

Chapter 18 misp. 17, chap. 24 misp. 22, chap. 32 misp. 22, chap. 33 misp. 34, chap. 49 misp. 43, chap. 54 misp. 52, chap. 55 misp. 53, chap. 59 misp. 61, chap. 65 misp. 63.
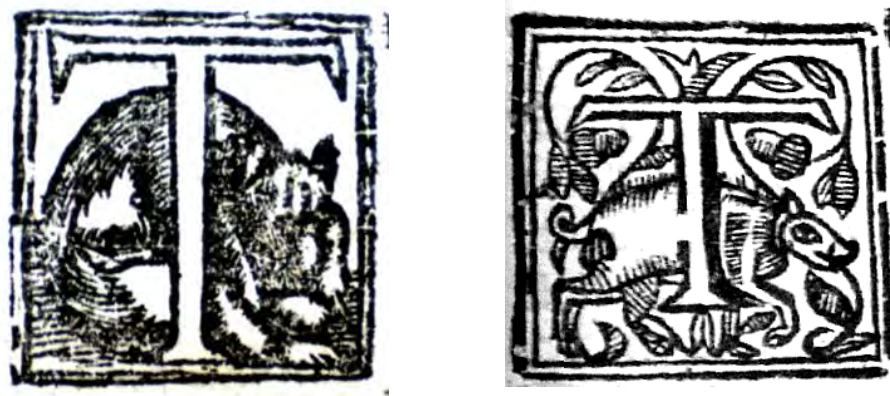

Figure 2. Initials $\mathrm{T}_{2}\left(\right.$ sig. $\mathrm{X}_{3}^{\mathrm{v}}$ ), $\mathrm{T}_{4}\left(\right.$ sig. $\mathrm{L}_{4}^{\mathrm{r}}$ )

Notes: In this copy gathering $\mathrm{V}$ presents an anomaly, since the order of the leaves breaks the textual continuity of the romance. The leaves are bound in the following order: $\left.V_{1}, V_{2}, V_{5}\right], V[6], V_{3}, V_{4}$, $\mathrm{V}[7], \mathrm{V}[8]$. In a quarto in eights a gathering is comprised of "two twice-folded sheets, one quired within the other" (Bowers 1949:201). The error in this copy is caused when the second fold of the sheet nested in is made in the wrong direction, thus altering the textual order. This mistake is attributable to the binder (cf. Gaskell 1972:147). I have consulted the two copies of the fourth edition in the Folger Shakespeare Library, neither of which presents the same anomaly.

\footnotetext{
${ }^{8}$ The fourth edition uses a different ornamental $\mathrm{T}$ featuring a boar, instead of a fox as in Creede's T2. I will designate it as $\mathrm{T}_{4}$ (see fig. 2). This initial heads chapters 10, 33, and 65 .
} 


\section{Volume 2}

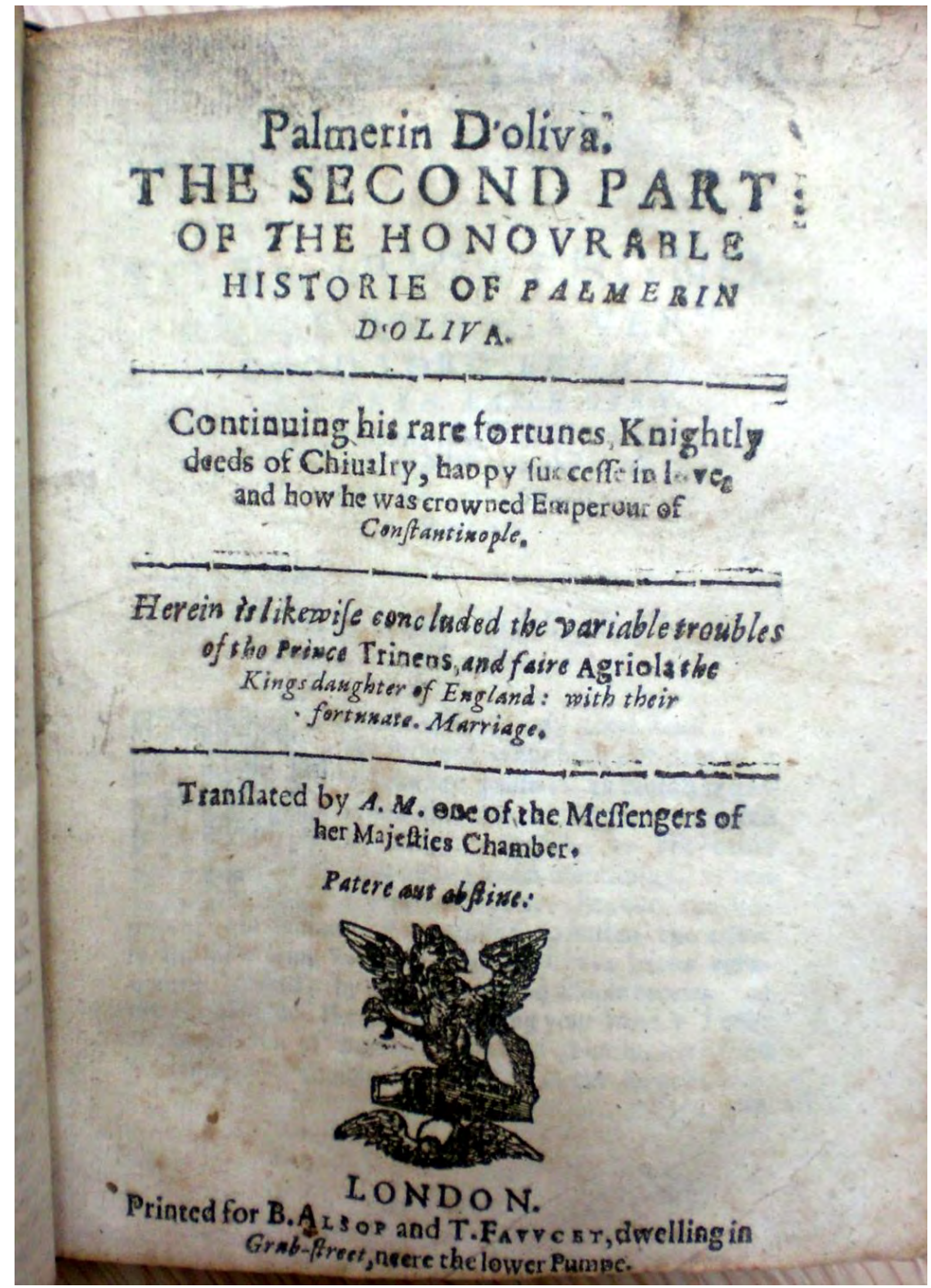

Figure 3. Palmerin d'Oliva, part II (London, 1637), title-page. 
Title-page: Palmerin D'oliva. | THE SECOND PART: | OF THE HONOVRABLE | HISTORIE OF PALMERIN | D'OLIVA. | [rule] Continuing his rare fortunes, Knightly | deeds of Chiualry, happy fuccelfe in love, | and how he was crowned Emperour of | Conftantinople. | [rule] Herein is likewife concluded the variable troubles | of the Prince Trineus, and faire Agriola the | Kings daughter of England: with their | fortunate. Marriage. | [rule] Tranllated by A. M. one of the Meffengers of | her Majelties Chamber. | Patere aut abftine: | [orn. McKerrow 339; Yamada 3] | LONDON. | Printed for B. ALSOP and T. FAVVCET, dwelling in | Grub-street, neere the lower Pumpe.

HT] [orn. Yamada 12] THE SECOND | PART OF THE ANTIENT AND HONORA- | ble Hiftory of Palmerin D'Oliva. Continuing his rare Fortunes, Knightly deedes of | Chiualry, happy fuccefse in Love, and how he was crow | ned Emperour of Conftantinople. Herein | is likewife concluded the variable trou- | bles of Tryneus, and faire Agriola | of England, with their for- $\mid$ tunate Marriage. Ec. [rule].

RT] [rule] The Hiftory of [Of NOSTYZAa1 ${ }^{\mathrm{v}}, \mathrm{LMRX}_{2}{ }^{\mathrm{v}}, \mathrm{MPQTV}_{3}{ }^{\mathrm{v}}$, ANOPQRSVXYZAaBb4 ${ }^{\mathrm{v}}$ ] Palmerin D'Oliva. [D'Oliva^STYZAa1 ${ }^{\mathrm{v}}$, $\mathrm{ORX}_{2}{ }^{\mathrm{v}}, \mathrm{TV}_{3}{ }^{\mathrm{v}}, \mathrm{ORSVXYZAa}_{4}^{\mathrm{v}}$; DOliva. $\left.\mathrm{K}_{4}^{\mathrm{v}}, \mathrm{L}^{\mathrm{v}}\right]$ Emperour of Conftantinople. PART. 2. [Conantnople $\mathrm{L}_{3}^{\mathrm{r}} ; 2$ turned T6,8 $; 2 \wedge \mathrm{A} 5,7^{\mathrm{r}}$, I1$2^{\mathrm{r}}, \mathrm{K} 5-6,8^{\mathrm{r}}, \mathrm{L} 2-4^{\mathrm{r}}, \mathrm{O} 2-3^{\mathrm{r}}, \mathrm{S} 5-6^{\mathrm{r}}, \mathrm{TVXYZAa} 5-8^{\mathrm{r}}, \mathrm{Aa}_{2}{ }^{\mathrm{r}}, \mathrm{Bb}_{5}{ }^{\mathrm{r}}$ ] [rule] [Oliva with turned $a \mathrm{~A}_{5}^{\mathrm{v}} ; \mathrm{F}_{7}{ }^{\mathrm{v}}-\mathrm{F}^{\mathrm{r}}$ invert the two parts of the RT; $\mathrm{G}^{\mathrm{v}}-\mathrm{G}_{7}^{\mathrm{r}}$ print 'The Hiftory of Palmerin D'Oliva.' in both parts of RT; G8 ${ }^{\mathrm{v}}-\mathrm{Hi}^{\mathrm{r}}$ print 'Emperour of Conftantinople. PART. 2.' in both parts of RT].

Collation: $4^{\circ}: \mathrm{A}^{-2} \mathrm{~B}^{8}(-2 \mathrm{~B} 7-8)$ [\$4 signed; misprinting $\mathrm{G}_{4}$ as $\mathrm{G}_{2}$, $\mathrm{J}[1]$ a $\mathrm{F}[1], \mathrm{H}_{4}$ as $\mathrm{H}_{2}, \mathrm{~N}[1]$ as $\mathrm{M}[1], \mathrm{O}_{3}$ as $\left.\mathrm{M}_{3}\right]$, 196 leaves unnumbered.

Contents: Ar ${ }^{\mathrm{r}}$ : title-page (verso blank). A2: [orn. Yamada 12] | 'TO THE RIGHT HONO- | RABLE AND HIS VERY | GOOD LORD EDWARD | DE VERE, EARLE OXEN- | ford, Vifcount, Bulbecke, Lord San- | ford of Badelefmere, and Lord | high Chamberlaine of | England. [rule] A. M. Wifheth full iffue of his $\mid$ noble defires.' rom. with 7-line initial [Yamada P1] (27 x 27 mm.). A3: [type orn.] 'TO THE FRIENDLY | READERS', ital. with 6-line initial [Yamada Y1] $(28 \times 27$ mm.). A4 $4^{\mathrm{r}}-\mathrm{Bb} 6^{\mathrm{v}}$ : HT and text [b.l.], chap. 1-67, chap. hd. in rom. except for proper names. Bb6 ${ }^{\mathrm{v}}$ : 'FINIS.' 
Catchwords: $\mathrm{A} 3^{\mathrm{r}}$ Sonne [Jon] $\mathrm{A}_{5}^{\mathrm{r}}$ (Fa-)vour [vour,] $\mathrm{A} 5^{\mathrm{v}}$ honor [honor,] A8 ${ }^{\mathrm{v}}$ Aneas [ÆEneas] B2 ${ }^{\mathrm{v}}$ CHAP. IV. [CHAP. III.] B6 ${ }^{\mathrm{v}}$ God [The] $\mathrm{B}^{\mathrm{v}}$ CHAP. VII. [CHAP. VI.] $\mathrm{D}^{\mathrm{v}}{ }^{\mathrm{v}}$ lignes, [fignes.] ${ }_{5}{ }^{\mathrm{r}}$ CHAP. XIII. [CHAP. XIIII.] $\mathrm{F}_{2}{ }^{\mathrm{r}}$ thinke [hinke] $\mathrm{F}_{2}{ }^{\mathrm{v}}$ colours [colours,] $\mathrm{F}_{3}{ }^{\mathrm{r}}$ Madam [Madam,] $\mathrm{G}_{1}{ }^{\mathrm{v}}$ any [further] $\mathrm{H}_{4} \mathrm{v}$ hereof [hereof,] $\mathrm{H}_{6}{ }^{\mathrm{r}}$ me, [me.] $\mathrm{K}_{5}^{\mathrm{v}}$ ber' [her,] $\mathrm{L}^{\mathrm{r}}$ ekéef [féeke] $\mathrm{L}^{\mathrm{v}}$ (apper-)tained, [taine,] $\mathrm{L}^{\mathrm{v}}$ (perfor-)mance [manen] $\mathrm{M}^{\mathrm{v}}$ thanks [thanks,] $\mathrm{M}_{4}^{\mathrm{v}}$ Madame, [Madam,] M8 $8^{\mathrm{r}}$ CHAP. XXXIII. [CHAP. XXXII.] $\mathrm{P}_{2}{ }^{\mathrm{r}}$ (boun-)den [den.] $\mathrm{P}_{4}{ }^{\mathrm{v}}$ (en-)tered [tred] $\mathrm{Q}_{2}{ }^{\mathrm{r}}$ Befide [Befide,] $\mathrm{Q}^{\mathrm{r}}$ Citie [Citty] $\mathrm{Q}^{\mathrm{v}}$ Hyppolita [Hypolita,] Q8 ${ }^{\mathrm{v}}$ CHAP. XLIV. [CHAP. XLIIII.] R4 ${ }_{4}^{\mathrm{r}}$ Ifle [IIle,] $\mathrm{S}_{4}^{\mathrm{r}}$ an [and] $\mathrm{T}_{1}{ }^{\mathrm{r}}$ Palmeri [Palmerin] $\mathrm{T}_{2} \mathrm{v}$ (be-)fore [fore:] $\mathrm{T}_{3}^{\mathrm{v}}$ honours [honors] $\mathrm{T}_{5} \mathrm{v}$ highnes [Highneffe] T $6^{\mathrm{v}}$ CHAP. LI. [CHAP. LIII.] V4 ${ }^{\mathrm{r}}$ (grea-)ter [ter,] V6 ${ }^{\mathrm{r}}$ Need[Néedleffe] $\mathrm{X}_{1}{ }^{\mathrm{r}}$ (La-)dy, [die,] $\mathrm{Y}_{2}{ }^{\mathrm{v}}$ Trineus [Tryneus] $\mathrm{Z}_{1}{ }^{\mathrm{v}}$ delight [delight,] $\mathrm{Z}_{3}^{\mathrm{r}}$ doth [do h] $\mathrm{Z}_{4}^{\mathrm{r}}$ faid [faid:] $\mathrm{Z}_{5}^{\mathrm{r}}$ meane [mean] Aa1 ${ }^{\mathrm{v}}$ defence [defence,] $\mathrm{Aa}_{2}{ }^{\mathrm{v}}$ (pa-)tience [tience,], $\mathrm{Aa}^{\mathrm{r}}{ }^{\mathrm{r}}$ (Em-)perour [perour,] Aa6 ${ }^{\mathrm{r}}$ highly [hlghly], Aa8 ${ }^{\mathrm{v}}$ nor [not].

Typography: 35 ll. 143 (157 to top rule of headline) x $89 \mathrm{~mm}$. $\left(\mathrm{A}_{5}^{\mathrm{v}}\right.$ ); text, black letter (and some roman and italic) $82 \mathrm{~mm}$. for 2011 ;; dedication: roman $82 \mathrm{~mm}$. $\left(\mathrm{A}_{2}{ }^{\mathrm{r}}\right)$; 'TO THE FRIENDLY | READERS': italic $94 \mathrm{~mm}$. $\left(\mathrm{A}_{3}{ }^{\mathrm{r}}\right)$. Chapter 4 misp. 3, chap. 19 misp. 18, chap. 23 misp. 24, chap. 33 misp. 32, chap. 59 misp. 57. Capitals used from Thomas Creede's stock (following Yamada 1994:84-86): B1 (ch. 21, 57), E1 (ch. 3, 14, 15, 18, 57, 63), C1 (ch. 34, 61), E1 (ch. 8), F1 (ch. 59), G1 (ch. 29), H1 (ch. 2, 20), L1 (ch. 25, 44), M1 (ch. 7, 52, 66), N1 (ch. 4, 19, 21, 24, 36, 40, 41, 53), P1 (sig. A2 ${ }^{\mathrm{r}}$, ch. 5, 22, 28, 31, 43, 50, 55), S1 (ch. 9, 16, 23, 65), T2 (ch. 27, 32, 37, 46, 49, 56, 58, 67), V1 (ch. 26, 64), $\mathrm{Y}_{1}\left(\right.$ sig. $\left.\mathrm{A} 3^{\mathrm{r}}\right){ }^{9}$

Notes: This copy lacks $\mathrm{Bb}_{7}{ }^{\mathrm{r}}$, which contains the translator's address to readers, an announcement and 'FINIS.' (verso blank); a facsimile reproduction has been added. On the title-page the year was cropped when the edges of the book were cut before binding (cf. Gaskell 1972:148), although it is visible on the other copies consulted. There is a textual lacuna at the beginning of $\mathrm{B}^{\mathrm{r}}$ (cf. catchword discrepancy); the 1616 edition used as copy-text reads as follows: 'God difpofed of him: made faft the doore after him, and with his fword drawne, and his Mantle wraped about his arme, went to fée how the Beastes would deale with him' (sig. $\mathrm{B}^{\mathrm{r}}$ ).

\footnotetext{
${ }^{9} \mathrm{~T}_{4}$ is used as the initial capital in chapters 12 and 17 ; see fig. 2 above.
} 
Other copies examined: Folger Shakespeare Library (STC 19160) copies 1 and 2.

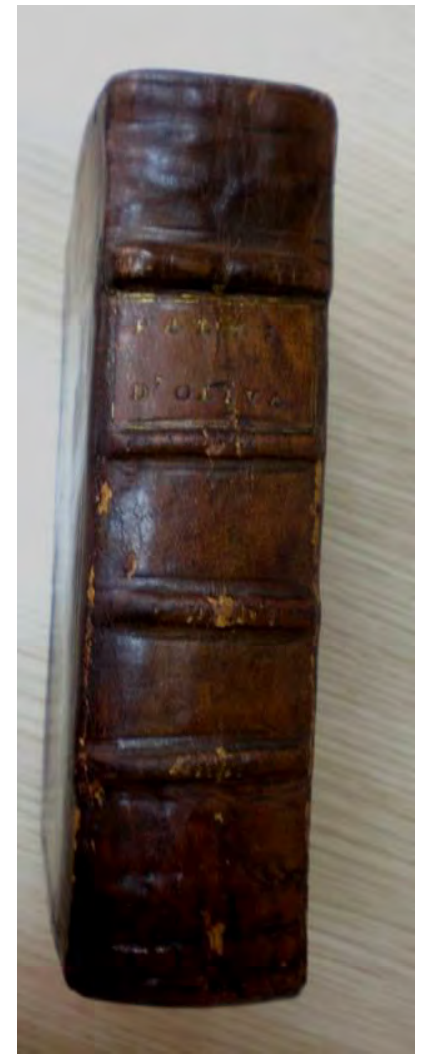

Figure 4. Binding and spine.

Binding: Brown leather in pasteboard with double-fillet borders blind-tooled on front and back cover; four raised bands across the spine of the book with title gold-lettered with decorative bands: 'PALM: | D'OLIVA' (see fig. 4). Front flyleaf with contemporary ownership inscriptions (see fig. 5).

Provenance: On the front flyleaf we can read the ownership inscriptions of Thomas Ottley, Richard Ottley and Marg[ar]et Wolryche (see fig. 5). We can infer that the book was bought by and bound for the Ottleys of Pitchford. ${ }^{10}$ It seems likely that the names

\footnotetext{
${ }^{10}$ For more information about this family, see Hawkesbury (1895).
} 
refer to Sir Richard Ottley (bap. 15 Sept. 1626), Gentleman of H. M. Privy Chamber, and his son Thomas Ottley (b. 30 Jan. 1650- $d$. 11 May, 1695). The connection between the Ottleys and the Wolryches began in 1625 with the marriage of Ursula Ottley (b. 9 Aug. 1607) to Sir Thomas Wolryche, Bt. (Hawkesbury 1895:365). ${ }^{11}$ The couple had twelve children, one being Francis (ca. 1627-1688). The Deeds and Papers Relating to the Dudmaston Estate of the Wolryche Family contain a "Declaration of release of obligation" (ref. 2922/3/48), dated 27 August 1675, relating to a Margaret Wolryche (b. 1653), daughter of Sir Francis Wolryche, who most probably is the woman who inscribed her name on the flyleaf of the Alicante copy. ${ }^{12}$

The University of Alicante Library acquired the book from $\mathrm{H}$. M. Fletcher (Wynches Barn, Much Hadham, Herts.) in 2012 for $£ 2,350.00$.

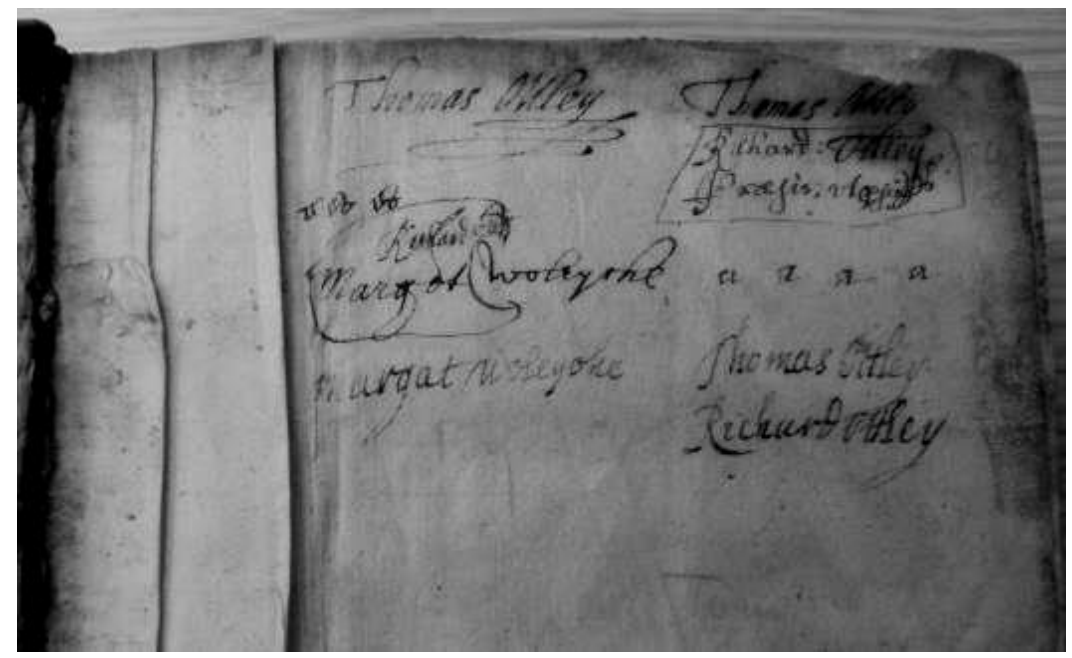

Figure 5. Front flyleaf.

\footnotetext{
${ }^{11}$ See Hopper (2004), but cf. the licence of alienation dated 1 Sept. 1626 in the Deeds and Papers Relating to the Dudmaston Estate of the Wolryche Family, ref. 2922/3/32.

${ }^{12}$ For the taste of women for Iberian romances of chivalry in seventeenth-century England, see Hackett (2000:66-68).
} 


\section{References}

Arber, Edward 1875-1894. A Transcript of the Registers of the Company of Stationers of London, 1554-77. 5 vols. London and Birmingham: Privately printed.

Bergeron, David M. 2004. "Munday, Anthony (bap. 1560, d. 1633)." ODNB 39: 739-746.

Bettoni, Anna 1995. "Il Palmerín de Olivia tradotto da Maugin: editori, storie e mode letterarie nella Francia del Cinquecento." "Il n'est nul si beau passe temps Que se jouer à sa Pensee": Studi di filologia e letteratura francese in onore di Anna Maria Finoli. Pisa: ETS: 173-201.

Bowers, Fredson 1949. Principles of Bibliographical Description. Princeton: Princeton University Press.

Cacho Blecua, Juan Manuel and María Jesús Lacarra. "Amadís: Base de datos de literatura caballeresca." Clarisel. Universidad de Zaragoza. <url: http://clarisel.unizar.es.>. Last accessed 17/07/2013.

Deeds and Papers Relating to the Dudmaston Estate of the Wolryche Family. Shropshire Archives, Shrewsbury.

Eisenberg, Daniel and $\mathrm{M}^{\mathrm{a}}$ Carmen Marín Pina 2000. Bibliografía de los libros de caballerías castellanos. Zaragoza: Prensas Universitarias de Zaragoza.

FB > see Pettegree (2007).

Galigani, Giuseppe 1966. "La versione inglese del Palmerín de Olivia." Eds. G. G. Mancini and G. di Stefano. Studi sul "Palmerín de Olivia." Istituto di Letteratura Spagnola e Ispano-Americana 13. Pisa: Università di Pisa, vol. 3: 239-288.

Gants, David L. 2004. "Creede, Thomas (b. in or before 1554, d. 1616)." ODNB 14: 128-129.

García Dini, Encarnación 1966. "Per una bibliografia dei romanzi di cavalleria: Edizioni del ciclo dei 'Palmerines.'” Eds. G. G. Mancini and G. di Stefano. Studi sul "Palmerín de Olivia." Istituto di Letteratura Spagnola e Ispano-Americana 13. Pisa: Università di Pisa, vol. 3: 5-43.

Gaskell, Philip 1972. A New Introduction to Bibliography. Oxford: Clarendon Press.

Hackett, Helen 2000. Women and Romance Fiction in the English Renaissance. Cambridge: Cambridge University Press.

Hamilton, Donna B. 2005. Anthony Munday and the Catholics, 1560-1603. Burlington, Vt.: Ashgate. 
Hawkesbury, Lord 1895. "The Family of Ottley of Pitchford." Transactions of the Shropshire Archaeological and Natural History Society, 2nd. ser. 7: 36138 o.

Hayes, Gerald R. 1925. "Anthony Munday's Romances of Chivalry." The Library, 4th ser. 6: 57-81.

— 1926. "Anthony Munday's Romances: A Postcript." The Library, 4th ser. 7: $31-38$.

Hill, Tracey 2004. Anthony Munday and Civic Culture: Theatre, History and Power in Early Modern London 1580-1633. Manchester: Manchester University Press.

IB > see Wilkinson (2010).

Hopper, Andrew J. 2004. "Wolryche, Sir Thomas, first baronet (1598-1668)." ODNB 60: 2-3.

Mancini, Giancarlo Guido and Giuseppe di Stefano eds. 1996. Studi sul "Palmerín de Olivia." 3 vols. Istituto di Letteratura Spagnola e IspanoAmericana 13. Pisa: Università di Pisa.

Marín Pina, María Carmen 1996. "El ciclo español de los Palmerines." Voz y Letra 7/2: 3-27.

Matthew, H. C. G. and Brian Harrison eds. 2004. Oxford Dictionary of National Biography. 61 vols. Oxford: Oxford University Press. [ODNB]

McKerrow, Ronald B. 1913. Printers' $\mathcal{E}$ Publishers' Devices in England $\mathcal{E}$ Scotland, 1485-1640. London: The Bibliographical Society.

Moore, Helen ed. 2004. Amadis de Gaule, Translated by Anthony Munday. NonCanonical Early Modern Popular Texts. Burlington, Vt.: Ashgate.

2010. "Ancient and Modern Romance." Eds. Gordon Braden et al. The Oxford History of Literary Translation in English, vol. 2: 1550-1660. Oxford: Oxford University Press: 333-346.

Munday, Anthony 1963 (1580). Zelauto: The Fountaine of Fame. Ed. Jack Stillinger. Carbondale, Ill.: Southern Illinois University Press.

Nelson, Alan H. 2004. "Vere, Edward de, seventeenth earl of Oxford (15501604)." ODNB 56: 286-289.

ODNB > see Matthew and Harrison (2004).

Patchell, Mary 1947. The "Palmerin" Romances in Elizabethan Prose Fiction. Columbia University Studies in English and Comparative Literature 166. New York, N.Y.: Columbia University Press.

Pettegree, Andrew et al. eds. 2007. French Vernacular Books: Books Published in the French Language before 1601. 2 vols. Leiden: Brill. [FB]

Phillips, Joshua 2010. English Fictions of Communal Identity, 1485-1603. Burlington, Vt.: Ashgate. 
Plomer, H. R. 1907. A Dictionary of the Booksellers and Printers who were at work in England, Scotland and Ireland from 1641 to 1667. London: Bibliographical Society.

Pollard, A.W. et al. eds. 1976-91. A Short-Title Catalogue of Books Printed in England, Scotland and Ireland 1475-1640. 3 vols. 2nd ed. London: Bibliographical Society. [STC]

Purser, William Edward 1904. Palmerin of England: Some Remarks on this Romance and on the Controversy concerning its Authorship. Dublin: Browne and Nolan.

STC > see Pollard (1976-1991).

Stefano, Giuseppe di ed. 2004 (1511). Palmerin de Olivia. In collaboration with Daniela Pierucci and with an introduction by $\mathrm{M}^{\mathrm{a}}$ Carmen Marín Pina. Los Libros de Rocinante 18. Alcalá de Henares: Centro de Estudios Cervantinos.

Thomas, Henry 1920. Spanish and Portuguese Romances of Chivalry: The Revival of the Romance of Chivalry in the Spanish Peninsula, and Its Extension and Influence Abroad. Cambridge: Cambridge University Press.

Turner, Celeste 1928. Anthony Mundy: An Elizabethan Man of Letters. University of California Publications in English 2/1. Berkeley, Calif.: University of California Press.

Wilkinson, Alexander S. ed. 2010. Iberian Books: Books Published in Spanish or Portuguese or in the Iberian Peninsula before 1601. Leiden: Brill. [IB]

Wilson, Louise 2011. "Playful Paratexts: The Front Matter of Anthony Munday's Iberian Romance Translations." Eds. Helen Smith and Louise Wilson. Renaissance Paratexts. Cambridge: Cambridge University Press.

Yamada, Akihiro 1994. Thomas Creede: Printer to Shakespeare and His Contemporaries. Tokyo: Meisei University Press.

How to cite this note:

Sánchez-Martí, Jordi. "The University of Alicante Library copy of Palmerin d'Oliva (London, 1637): A Bibliographical Description." SEDERI 23 (2013): 123-137.

Author's contact: jordi.sanchez@ua.es

Submission: 28/02/2013 - Acceptance: 24/04/2013 